\title{
Flows of nitrogen in a mesocosm experiment in the Baltic Sea
}

\author{
Fred Sörensson, Karin Pettersson, Johanne-Sophie Selmer, Elisabeth Sahlsten
}

Department of Marine Microbiology, University of Göteborg, Carl Skottsbergs Gata 22, S-413 19 Göteborg, Sweden

\begin{abstract}
Nitrogen transformations in a Baltic Sea plankton community were studied in a mesocosm $\left(100 \mathrm{~m}^{3}\right)$ using additions of initially ${ }^{15} \mathrm{~N}$ labelled ammonium and subsequently unlabelled nitrate to the entire mesocosm. Labelling of different size fractions during the experiment showed that there was a temporal difference in labelling peaks between fractions dominated by producers and consumers, with the latter showing a lag of 30 to $80 \mathrm{~h}$. The size fraction $12-35 \mu \mathrm{m}$ responded fastest to ${ }^{15} \mathrm{~N}$ labelling and also attained the highest atom $\%{ }^{15} \mathrm{~N}$. The amount of ${ }^{15} \mathrm{~N}$ recovered in particulate, dissolved and sedimented nitrogen decreased with time, and only $53 \%$ of the amount initially present was detected after $12 \mathrm{~d}$ of sampling. This was probably due to incomplete capture of sedimenting material. After $10 \mathrm{~d}$, $14 \%$ of the added ${ }^{15} \mathrm{~N}$ could be recovered in the total dissolved nitrogen. The $\mathrm{C} / \mathrm{N}$ ratio of both suspended and sedimented material decreased during the experiment. The value obtained for the sediment was always higher than the value noted for suspended material. A method is described for determining nutrient uptake and regeneration in the presence of an existent label. The uptake determinations showed that the order of importance of the nitrogenous nutrient sources was ammonium $>$ urea $>$ nitrate, except after the nitrate addition, when nitrate uptake dominated. The rates of ammonium regeneration showed a sharp increase $40.5 \mathrm{~h}$ after the labelling of the mesocosm, and after the maximal labelling of the size fraction $<35 \mu \mathrm{m}$, presumably due to an increased grazing pressure. On average, rates of ammonium regeneration were $50 \%$ higher than those of ammonium uptake.
\end{abstract}

\section{INTRODUCTION}

Little is known about the time scales of the flow of material through the trophic levels from primary producers to different consumer levels in the planktonic food chain. One possible way to study this is to look at the ecosystem within an enclosure, thus avoiding some of the problems usually encountered when studying the free water masses of the pelagic environment. These difficulties, due to patchiness, lateral transport and migratory movement, are lessened and a representative, multitrophic ecosystem with natural populations can be sustained within the enclosure for a limited amount of time. The use of such mesocosms for different experimental purposes has been extensively reported (Steele 1979, Grice \& Reeve 1982, Davies 1983).

Transformations and flows of nitrogen between different biological and chemical compartments are crucial processes in the marine environment. Over the years, several types of enrichment studies have been performed in mesocosm experiments:

(1) Eutrophication experiments in which unlabelled nutrients were added to the enclosure. Rates of nutrient flux have either been calculated from changes in nutrient concentrations or determined in separate isotope labelling incubations. For example, Harrison et al. (1977) reported the effects of nutrient additions (nitrate, phosphate and silicate) on phytoplankton growth, and concluded that nitrogen uptake and sedimentation were mainly a function of nutrient addition rate. Rates of ammonium and nitrate uptake were determined in separate bottle incubations, while remineralization and sedimentation rates were calculated from concentration flux data.

(2) Experiments in which an isotopic label has been added directly to the enclosure, and the labelling of different fractions studied. Harrison \& Davies (1977) reported ${ }^{15} \mathrm{~N}$ uptake in < $202 \mu \mathrm{m}$ and $>202 \mu \mathrm{m}$ particles. Ducklow et al. (1986) described the ${ }^{14} \mathrm{C}$ labelling of 6 different size fractions after the addition of ${ }^{14} \mathrm{C}$ glucose to the enclosure. They found that very little of the glucose taken up by bacteria was transferred into larger size fractions. In some experiments, rates of uptake and regeneration have been calculated from in situ changes in atom $\%{ }^{15} \mathrm{~N}$. This approach has been 
reported by Hattori et al. (1980) and Koike et al. (1982). The latter workers also used size fractionations of 8 and 1 um.

In the present paper, we report a mesocosm experiment carried out in the northern Baltic proper in July 1985. In this area salinity is ca $7 \%$ and the inorganic nutrients in the photic zone are almost completely depleted during summer. Autotrophic production is thus mainly based on regenerated nutrients. The study combined the approaches described in (1) and (2) above. ${ }^{15} \mathrm{~N}$ label was added to the enclosure as ammonium, which should be rapidly assimilated by primary producers and also by heterotrophic bacteria. Samples of particulate material were separated into 5 size fractions and ${ }^{15} \mathrm{~N}$-incorporation into these determined. This enabled us to follow the flow of nitrogen from phytoplankton/bacteria to other trophic levels. In addition, rate determinations of nitrogen nutrient uptake and ammonium regeneration were performed in separate enrichment incubations, in which labelled nutrients were added to water collected from the enclosure. We present equations for calculating the rates of nutrient uptake and ammonium regeneration for incubations carried out using prelabelled water. Measurement of concentration and ${ }^{15} \mathrm{~N}$ labelling in the dissolved, suspended and sedimented particulate matter enabled us to estimate a budget of the added label for the time investigated.

This study was part of an interdisciplinary project also including hydrography, hydrodynamics, community structure, chlorophyll, chemical measurements (carbon, amino acids, oxygen), rate measurements $\left({ }^{14} \mathrm{C}\right.$ and ${ }^{3} \mathrm{H}$ ) and grazing experiments (Wulff \& Koop 1989).

\section{MATERIALS AND METHODS}

Enclosure and ${ }^{15} \mathrm{~N}$ labelling. The enclosure was situated outside the Askö Laboratory, on the Swedish east coast (Fig. 1), in a bay with a maximum depth of $9 \mathrm{~m}$. Although well-protected from wind and waves, this area had continuous exchange of water with its surroundings.

The enclosure was constructed as follows. The upper part was a cylinder with diameter $4.8 \mathrm{~m}$ and depth $4.0 \mathrm{~m}$. Beneath this the enclosure was cone-shaped for a length of $4.8 \mathrm{~m}$. Walls were $0.5 \mathrm{~mm}$ thick, and made of Plastolene 946 . Total volume was $100 \mathrm{~m}^{3}$ It was uncovered at the top, and protruded ca $0.5 \mathrm{~m}$ above the water surface. It was filled with well-mixed surface water to avoid salinity stratification. The enclosure was suspended from a support structure (flotation collar) and held rigid by $20 \mathrm{~kg}$ weights hung by ropes from the sides. A polyethylene funnel (diameter $500 \mathrm{~mm}$ ) was attached at the bottom of the cone, and from this a hose

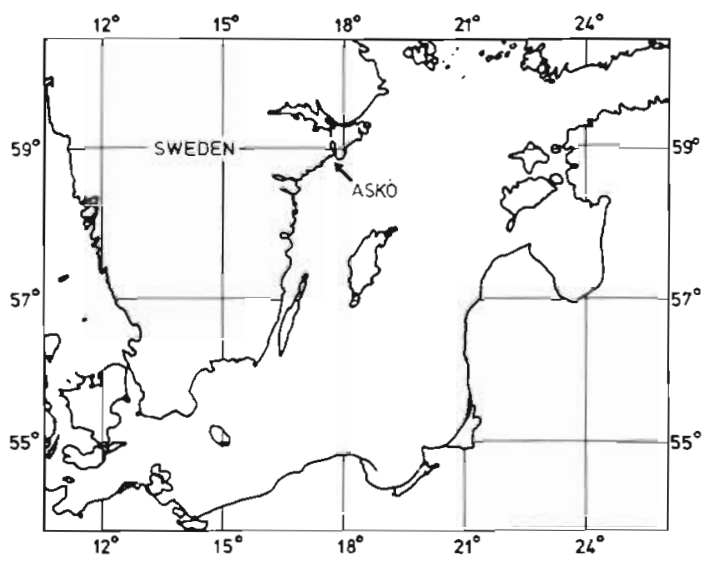

Fig. 1. The Baltic Sea. Askö area where the enclosure was situated is indicated by an arrow

was connected to a pump at the surface, enabling sampling of sedimented material.

On the 7 July, at 19:30 h local time (zero hours for the experiment), $168.2 \mathrm{mmol}$ of ${ }^{15} \mathrm{~N}$ labelled ammonium chloride (99 atom $\left.\%{ }^{15} \mathrm{~N}\right)$ was mixed into the water of the enclosure. After $132 \mathrm{~h}$ (13 July), ca $6 \mu \mathrm{mol} \mathrm{l} \mathrm{l}^{-1}$ of unlabelled nitrate and $0.5 \mu \mathrm{mol} \mathrm{l}^{-1}$ of phosphate were added. The main reason for this was to facilitate a parallel study of the effect of a switch from ammonium to nitrate on the photosynthetic quotient. On 17 July (after $240 \mathrm{~h}$ ), the whole enclosure was covered with black plastic sheets and darkened, to allow a longer period of respiration studies. The mesocosm was studied intensively until 18 July.

Sampling. Samples from depths of 0 to $6 \mathrm{~m}$ were taken with a tube sampler (length $2 \mathrm{~m}$, volume $12.7 \mathrm{l}$ ) and the water was then gently mixed in a $60 \mathrm{l}$ carboy to obtain uniform samples. Unless otherwise stated, all filters used were Whatman GF/F glass fiber filters, precombusted for $2 \mathrm{~h}$ at $450^{\circ} \mathrm{C}$ and rinsed with the sample if the filtrate was to be collected.

Nutrients. Nutrients were analysed according to the following methods: ammonium by the phenol-hypochlorite method as described by Koroleff (1976): urea by an adaptation of the diacetyl monoxime reaction (Newell et al. 1967) for the Technicon AutoAnalyzer (DeManche et al. 1973); nitrite and nitrate by Technicon AutoAnalyzer I according to Armstrong et al. (1967). Phosphate was measured (by A. Tobiesen) using the molybdenum blue method according to Koroleff (1976).

Total dissolved nitrogen. This was sampled by collecting the filtrate in polyethylene bottles and preserved by rapid freezing in dry ice/ethanol. Before analysis, the samples were rapidly thawed in a microwave oven. Dissolved organic nitrogen and ammonium were oxidized to nitrate by autoclaving together with persulfate and subsequently converted to nitrite by passage through a cadmium reductor accord- 
ing to Koroleff (1976). The nitrite was extracted for ${ }^{15} \mathrm{~N}$ analysis using a modified version of the method described by Olson (1981). After adding reagents, the formed azodye was concentrated on a disposable octadecylsilane Sep Pak separation cartridge (Waters Associates, Milford, Mass., USA). The column containing the sample was initially rinsed with $5 \mathrm{ml} 50 \%$ methanol in water acidified with phosphoric acid, and then the sample was eluted using $6 \mathrm{ml} 80 \%$ methanol made alkaline with $\mathrm{NaOH}$. Volumes of $1 \mathrm{ml}$ phosphoric acid $(1 \mathrm{M})$ and $3 \mathrm{ml}$ carbon tetrachloride were added to the eluate. The sample was then washed in turn with $2 \times 3 \mathrm{ml} 1 \mathrm{M} \mathrm{HCl}, 2 \times 3 \mathrm{ml} 2 \mathrm{MNaOH}$ and $2 \times 3 \mathrm{ml}$ distilled water. The solvent was evaporated and the azodye collected on a filter. This was then dried in a desiccator and the ${ }^{15} \mathrm{~N}$ content analysed as described for particulate material below.

Particulate material. Samples for particulate organic carbon and nitrogen were collected on filters and analysed on a Carlo Erba 1106 elemental analyser.

${ }^{15} \mathrm{~N}$ distribution in different fractions. Fractionations of the particulate material were performed at $4.5,14.5$, $38,70.5,118.5,187$, and $252 \mathrm{~h}$ after the ${ }^{15} \mathrm{~N}$ addition. In order to obtain the size fractions, a multistage fractionation tower (Williams 1981) was used. A combination of Nitex nets and Nuclepore filters gave the following operational size fractions: $<5,5-12,12-35,35-100$ and $>100 \mu \mathrm{m}$. At some occasions separate zooplankton nets, 100 and $250 \mu \mathrm{m}$, were used to isolate the fractions of the larger zooplankton. The material from the size fractions were collected on Whatman GF/F filters for subsequent analysis. On 2 occasions, organisms in the different size fractions were counted and identified to species (by A. Tobiesen and S. Johansson).

After fractionation, the particulate material was analysed for ${ }^{15} \mathrm{~N}$ content. Conversion of particulate organic nitrogen to dinitrogen gas and the subsequent measurement of the ${ }^{14} \mathrm{~N} /{ }^{15} \mathrm{~N}$ isotope ratio was done by direct Dumas combustion according to Kristiansen \& Paasche (1982). On 3 occasions the particulate carbon and nitrogen content of the different size fractions were also measured.

Sedimented material was pumped out daily for determination of sedimentation rate. A subsample was analysed for particulate carbon, nitrogen, and ${ }^{15} \mathrm{~N}$ content as described above.

Rate measurements. Subsamples were dispensed into 2.61 polycarbonate bottles. To these the appropriate labelled enrichments were added as described below. The bottles were incubated for about $4 \mathrm{~h}$ at $3 \mathrm{~m}$ depth outside the enclosure.

Uptake of nitrogen nutrients. The equations usually used in ${ }^{15} \mathrm{~N}$ uptake studies, as presented by Dugdale \& Goering (1967), are based on the assumption that the background labelling of the nutrient present before the
${ }^{15} \mathrm{~N}$-addition represents the level of natural abundance $\left(0.366\right.$ atom $\left.\%{ }^{15} \mathrm{~N}\right)$. In the present case, the labelling of the entire enclosure with ${ }^{15} \mathrm{~N}$ created an unknown background labelling of the nutrient. Consequently, parallel samples that received an addition of either labelled (99 atom $\%{ }^{15} \mathrm{~N}$ ) or unlabelled ammonium, nitrate or urea were used. To increase precision in the measurements, substrate additions were 5 umol $\mathrm{N}^{-1}$ so as to achieve saturated concentrations. Because of the high substrate concentrations and the limited incubation time, effects from isotope dilution of the substrate could be neglected. After incubation, the particulate organic matter was collected on GF/F filters for subsequent analysis of atom $\%{ }^{15} \mathrm{~N}$ as described above.

The equation presented by Dugdale \& Goering (1967) for determining the rate of nutrient uptake is given as

$$
\mathrm{P}_{14}=\mathrm{PN} \frac{\mathrm{da} \mathrm{a}_{1} / \mathrm{dt}}{\mathrm{a}_{4}-\mathrm{a}_{1}}
$$

where $\mathrm{P}_{14}=$ rate of nitrogenous nutrient uptake; $\mathrm{PN}=$ amount of particulate nitrogen per unit volume; $\mathrm{a}_{1}=$ atom $\%{ }^{15} \mathrm{~N}$ in the particulate material; $\mathrm{a}_{4}=$ atom $\%{ }^{15} \mathrm{~N}$ in the nutrient after enrichment; and $t=$ duration of the experiment.

Integrating Eq. (1) and assuming $\mathrm{P}_{14}, \mathrm{a}_{4}$ and $\mathrm{PN}$ to be constant, results in:

$$
\mathrm{P}_{14} \mathrm{t}=\mathrm{PN} \ln \left\{1+\left[\mathrm{a}_{1}(\mathrm{t})-\mathrm{a}_{1}(0)\right] /\left[\mathrm{a}_{4}-\mathrm{a}_{1}(\mathrm{t})\right]\right\}
$$

Assuming $\left[\mathrm{a}_{1}(\mathrm{t})-\mathrm{a}_{1}(0)\right] /\left[\mathrm{a}_{4}-\mathrm{a}_{1}(\mathrm{t})\right]$ to be small compared to 1 , the following approximation [which is the same as Eq. (5) in Collos 1987] is obtained:

$$
P_{14} t=P N \frac{a_{1}(t)-a_{1}(0)}{a_{4}-a_{1}(t)}
$$

where $a_{1}(0)=$ initial atom $\%{ }^{15} \mathrm{~N}$ in the particulate material; and $a_{1}(t)=$ final atom $\%{ }^{15} \mathrm{~N}$ in the particulate material. Here $a_{4}$ is given by the equation:

$$
\mathrm{a}_{4}=\frac{\mathrm{C}^{15} \mathrm{n}+\mathrm{V} \cdot{ }^{15} \mathrm{~N}}{\mathrm{C}+\mathrm{V}}
$$

where ${ }^{15} \mathrm{n}=$ natural ${ }^{15} \mathrm{~N}$ abundance $(0.366 \%) ;{ }^{15} \mathrm{~N}=$ atom $\%{ }^{15} \mathrm{~N}$ of the added nutrient; $\mathrm{C}=$ in situ concentration of the nutrient per unit volume; $\mathrm{V}=$ added amount of the nutrient per unit volume.

Eqs. (3) and (4) are the equations normally used in uptake studies where there is no background labelling of the nutrient pool and the particulate pool. In this mesocosm experiment, the background labelling was unknown and hence ${ }^{15} \mathrm{n}$ can be substituted by $\mathrm{X}=$ the unknown background labelling of the nutrient in Eq. (4).

For the ${ }^{14} \mathrm{~N}$-incubation, the corresponding equation would be:

$$
\mathrm{b}_{4}=\frac{\mathrm{C} \cdot \mathrm{X}+\mathrm{V}^{15} \mathrm{n}}{\mathrm{C}+\mathrm{V}}
$$


where $\mathrm{b}_{4}=$ atom $\%{ }^{15} \mathrm{~N}$ in the nutrient after enrichment. The amount of added nutrient is the same in both experiments. $X$ can be solved for both equations and eliminated by equating the resulting equations. Thus $b_{4}$ can be expressed as a function of $a_{4}$ :

$$
\mathrm{b}_{4}=\mathrm{a}_{4}-\frac{\mathrm{V}^{15} \mathrm{~N}-\mathrm{V} \cdot{ }^{15} \mathrm{n}}{\mathrm{C}+\mathrm{V}}
$$

The rate of nutrient uptake in the ${ }^{14} \mathrm{~N}$ incubation can be expressed as:

$$
P_{14} t=\frac{P N \cdot\left[S-a_{1}(0)\right]}{b_{4}-S}
$$

where $\mathrm{S}=$ final atom $\%{ }^{15} \mathrm{~N}$ in the particulate material (in the ${ }^{14} \mathrm{~N}$ incubation).

In the present study we assumed that the nitrogen uptake was equal in both cases of incubations (i.e. ${ }^{14} \mathrm{~N}$ and ${ }^{15} \mathrm{~N}$-labelled nutrient addition), and by equating Eqs. (3) and (7) for both incubations, $P_{14}$ can be eliminated and an equation for $\mathrm{a}_{4}$ found:

$$
a_{4}=\frac{V\left({ }^{15} N-{ }^{15} n\right)\left[a_{1}(0)-a_{1}(t)\right]}{(C+V)\left[S-a_{1}(t)\right]}+a_{1}(0)
$$

Hence, the resulting $a_{4}$ can be used in Eq. (3) and the rate of nutrient uptake can be calculated:

$$
P_{14}=\frac{1}{t} \cdot \frac{P N}{\frac{V}{C+V} \cdot \frac{{ }^{15} N-{ }^{15} n}{a_{1}(t)-S}-1}
$$

The uptake rates were corrected to in situ uptake rates by assuming Michaelis-Menten kinetics and

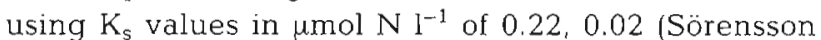
\& Sahlsten 1987) and 0.27 (Kristiansen 1983) for ammonium, nitrate, and urea uptake, respectively.

Regeneration of ammonium. The rate of ammonium regeneration can be determined with an ${ }^{15} \mathrm{~N}$ isotope dilution technique and calculated according to the Blackburn-Caperon model (Blackburn 1979, Caperon et al. 1979). This model presupposes that the added ${ }^{15} \mathrm{~N}$-ammonium may be assimilated, and that the dilution of the labelled ammonium pool is only brought about by ammonium originating from organic material formed before the start of the incubation.

In the Blackburn-Caperon model, the observed atom $\%{ }^{15} \mathrm{~N}$ is corrected for background labelling by subtracting the natural ${ }^{15} \mathrm{~N}$ abundance $\left({ }^{15} \mathrm{n}=0.366\right.$ atom $\%$ ${ }^{15} \mathrm{~N}$ ). This was valid only for the first sampling prior to the labelling of the enclosure. After labelling, the compounds that were mineralized contained an unknown amount of label. Analogous to the uptake equations, the natural ${ }^{15} \mathrm{~N}$ abundance was therefore replaced by a value (here called $\mathrm{Y}$ ) representing the atom $\%{ }^{15} \mathrm{~N}$ in the organic material that is mineralized during the time of incubation. In order to determine $Y$, the regeneration rate had to be measured in parallel incubations with additions of either ${ }^{14} \mathrm{~N}$ - or ${ }^{15} \mathrm{~N}$-ammonium.

Both ${ }^{14} \mathrm{~N}$ - and ${ }^{15} \mathrm{~N}$-enrichments were done in duplicate bottles, except on the last 2 sampling occasions. The enrichment amounted to $4 \mu \mathrm{mol} \mathrm{N} \mathrm{I}^{-1}$ (50 atom \% ${ }^{15} \mathrm{~N}$ for those receiving labelled ammonium). Triplicate samples for analysis of ammonium concentration and determination of the atom $\%{ }^{15} \mathrm{~N}$ in the ammonium pool were taken immediately after the ammonium addition and at the end of the incubation from the same polycarbonate bottle. Extraction reagents were added to the ${ }^{15} \mathrm{~N}$ samples, which were then stored in dark glass bottles until the solid phase extraction, according to Selmer \& Sörensson (1986).

The isotope dilution incubation could in both cases be described by the Blackburn-Caperon model Assuming that the parallel incubations gave the same rate of regeneration, these equations could be considered equal. To determine $Y$, we had to solve the equation:

$$
f(Y)=P \quad \ln \frac{R_{0}-Y}{R_{t}-Y}-C \cdot \operatorname{In} \frac{Y-N_{0}}{Y-N_{t}}=0
$$

where

$$
\begin{aligned}
& \mathrm{P}=\frac{\mathrm{P}_{0}-\mathrm{P}_{\mathrm{t}}}{\ln \frac{\mathrm{P}_{0}}{\mathrm{P}_{\mathrm{t}}}} \\
& \mathrm{C}=\frac{\mathrm{C}_{0}-\mathrm{C}_{\mathrm{t}}}{\ln \frac{\mathrm{C}_{0}}{\mathrm{C}_{\mathrm{t}}}}
\end{aligned}
$$

in which $P_{0}=$ initial ammonium concentration, $P_{t}=$ final ammonium concentration, $\mathrm{R}_{0}=$ initial atom $\%{ }^{15} \mathrm{~N}$, $\mathrm{R}_{\mathrm{t}}=$ final atom $\%{ }^{15} \mathrm{~N}$ in the ${ }^{15} \mathrm{~N}$ enrichment; and $\mathrm{C}_{0}=$ initial ammonium concentration, $C_{t}=$ final ammonium concentration, $\mathrm{N}_{0}=$ initial atom $\%{ }^{15} \mathrm{~N}$, and $\mathrm{N}_{\mathrm{t}}=$ final atom $\%{ }^{15} \mathrm{~N}$ in the ${ }^{14} \mathrm{~N}$-enrichment. Since the incubations with ${ }^{14} \mathrm{~N}$ and ${ }^{15} \mathrm{~N}$ additions were carried out under identical conditions, $\mathrm{P}$ and $\mathrm{C}$ can be assumed approximately equal. Putting $\mathrm{P}=\mathrm{C}$ we would get the first approximation:

$$
Y_{0}=\frac{R_{0} \cdot N_{t}-R_{t} \cdot N_{0}}{R_{0}-R_{t}+N_{t}-N_{0}}
$$

A second approximation of $Y$ was then given by Newton's method:

$$
\mathrm{Y}=\mathrm{Y}_{0}-\frac{f\left(\mathrm{Y}_{0}\right)}{f^{\prime}\left(\mathrm{Y}_{0}\right)}
$$

where

$$
\begin{gathered}
f\left(Y_{0}\right)=(P-C) \cdot \ln \frac{R_{0}-N_{0}}{R_{t}-N_{t}} \\
f^{\prime}\left(Y_{0}\right)=\frac{\left(R_{0}-R_{t}+N_{t}-N_{0}\right)^{2}}{\left(R_{0}-N_{0}\right)\left(R_{t}-N_{t}\right)} \cdot\left[\frac{P}{R_{0}-R_{t}}+\frac{C}{N_{t}-N_{0}}\right]
\end{gathered}
$$


Using Newton's method of approximation once more would not increase the accuracy, since this correction would be much smaller than the uncertainty resulting from the measurement. By inserting $Y$ instead of the natural isotope abundance in the Blackburn-Caperon model, the rate of regeneration could be calculated.

\section{RESULTS}

During the experiment the weather was sunny and with no precipitation. Water temperature was ca $18^{\circ} \mathrm{C}$.

\section{Dissolved material}

Concentrations of nitrate and nitrite were very close to zero until the day of the nitrate addition (Fig. 2). A sharp increase in nitrite concentration occurred $40 \mathrm{~h}$ after the nitrate addition (at $184 \mathrm{~h}$ ). The low level of ammonium concentration, to which the system had adjusted $36 \mathrm{~h}$ after the ${ }^{15} \mathrm{~N}$-ammonium addition, varied between undetectable and $0.27 \mu \mathrm{mol} \mathrm{l}^{-1}$ (Fig. 2). The urea-N concentration was highest at the beginning, $1.19 \mu \mathrm{mol} \mathrm{Nl^{-1 }}$, but stabilized later between 0.60 and $0.75 \mu \mathrm{mol} \mathrm{N} 1^{-1}$.

The concentration of dissolved organic nitrogen (estimated as total dissolved nitrogen minus ammonium, nitrate and nitrite) was between 13.3 and $12.3 \mu \mathrm{mol} N$ $\mathrm{l}^{-1}$, with the lower values detected towards the end of the period.

The phosphate concentration before the addition at $132 \mathrm{~h}$ was below $0.05 \mu \mathrm{mol} \mathrm{l}^{-1}$. After the addition, the concentration showed a steady decrease. The average

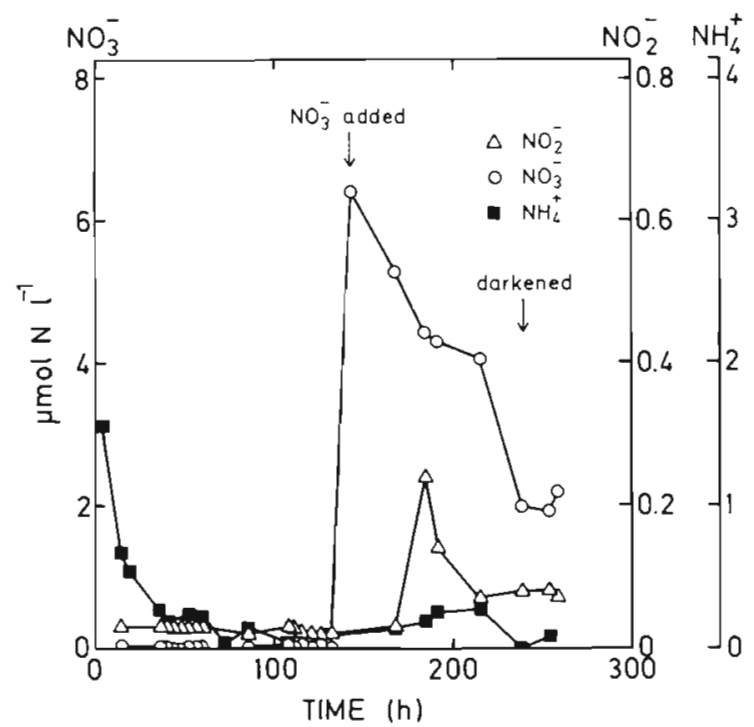

Fig. 2. In situ concentration of nitrate, nitrite and ammonium Hours are measured from the start of the experiment, i.e. the addition of ${ }^{15} \mathrm{~N}$-ammonium. Note different scales for nitrate versus nitrite and ammonium rate of this disappearance over the 4 following days yields a phosphate uptake of $1.5 \mathrm{nmol} \mathrm{l}^{-1} \mathrm{~h}^{-1}$.

The ${ }^{15} \mathrm{~N}$ labelling in the dissolved nitrogen pool increased from 1.10 atom $\%{ }^{15} \mathrm{~N}$ on Day 4 to 1.44 atom $\%{ }^{15} \mathrm{~N}$ on Day 12. If this latter value is corrected for the nitrate addition at $132 \mathrm{~h}$ by assuming that all the nitrate present was unlabelled, the remaining dissolved nitrogen would contain 1.69 atom $\%{ }^{15} \mathrm{~N}$. This accounted for $14 \%$ of the total ${ }^{15} \mathrm{~N}$ in the enclosure.

\section{Particulate material}

The particulate carbon content was between 23.5 and $36.4 \mu \mathrm{mol}^{-1}$ and the particulate nitrogen varied from 3.0 to $4.9 \mu \mathrm{mol} 1^{-1}$. There were no systematic variations of either particulate carbon or nitrogen with time, although a trend was observed in the $\mathrm{C} / \mathrm{N}$ ratio of the particulate material (Fig. 3 ). The ratio was 8.8 before the ammonium addition, but was clearly affected by the 2 nitrogen additions. The ratio decreased to beween 7.5 and 8.0 after the initial ammonium addition, and then to 6.5 after the addition of nitrate.

The total amount of particulate nitrogen (PN) did not show any apparent correlation to other parameters. On 3 occasions, the PN content in different size fractions was determined (Table 1). An increase in the 2 smallest fractions and a decrease in the fraction between 12 and 35 $\mu \mathrm{m}$ was noted, while the $\mathrm{C} / \mathrm{N}$ ratio decreased in all size fractions. These determinations must be viewed with some caution, because the sum of particulate nitrogen in the fractions after $122 \mathrm{~h}$ only amounted to about $60 \%$ of the PN measured in the unfractionated sample. However, this seems to be a problem related to fractionation experiments. Larsson \& Hagström (1982) reported, when measuring primary production, losses in fractionated

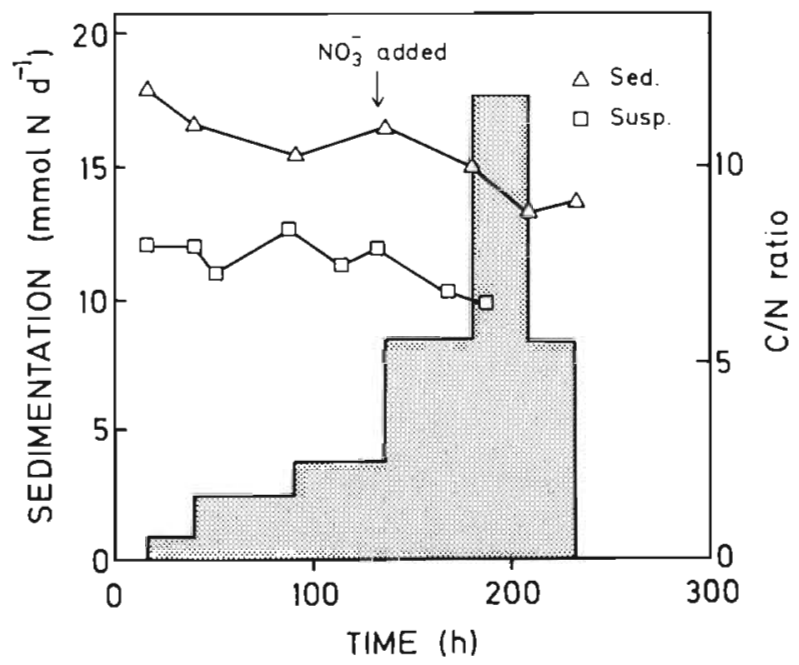

Fig. 3. Sedimentation rate and $\mathrm{C} / \mathrm{N}$ ratio in sedimented and suspended material. Time scales as in Fig. 2 
samples compared with intact seawater that was increasing linearly with increasing number of fractions. For 5 size fractions they estimated the loss to be $30 \%$.

\section{Sedimented material}

The $\mathrm{C} / \mathrm{N}$ ratio of the sedimented material decreased steadily during the experiment. The sedimentation rate reached a maximum after $208 \mathrm{~h}$, on 16 July (Fig. 3; Table 2).

After $230 \mathrm{~h}, 4.3 \%$ of the nitrogen added as ${ }^{15} \mathrm{~N}$ labelled ammonium had sedimented. The total sedimentation in the enclosure until then was $62 \mathrm{mmol}$ nitrogen and $600 \mathrm{mmol}$ carbon with the $\mathrm{C} / \mathrm{N}$ ratio in the sedimented matter decreasing from 12 to 9 over the period investigated. This can be compared to the $360 \mathrm{mmol}$ of particulate $\mathrm{N}$ present initially in the entire enclosure if using a concentration of particulate nitrogen of $3.6 \mu \mathrm{mol} \mathrm{I}^{-1}$.

\section{Recovery of ${ }^{15} \mathrm{~N}$}

When attempting to recover all the ${ }^{15} \mathrm{~N}$ present at the start of the experiment by summation of the amounts in particulate, dissolved (organic + inorganic) and sedimented nitrogen (Fig. 4), the recovered total amount decreased steadily over the period, from $65 \%$ of the initial amount on Day $4(76 \mathrm{~h})$ to $53 \%$ on Day $12(256 \mathrm{~h})$. This was mainly due to a continuous decrease in the labelling of the particulate nitrogen, which contained the major part of the ${ }^{15} \mathrm{~N}$. The amount of ${ }^{15} \mathrm{~N}$ in the sedimented matter and the dissolved fraction was rising steadily.

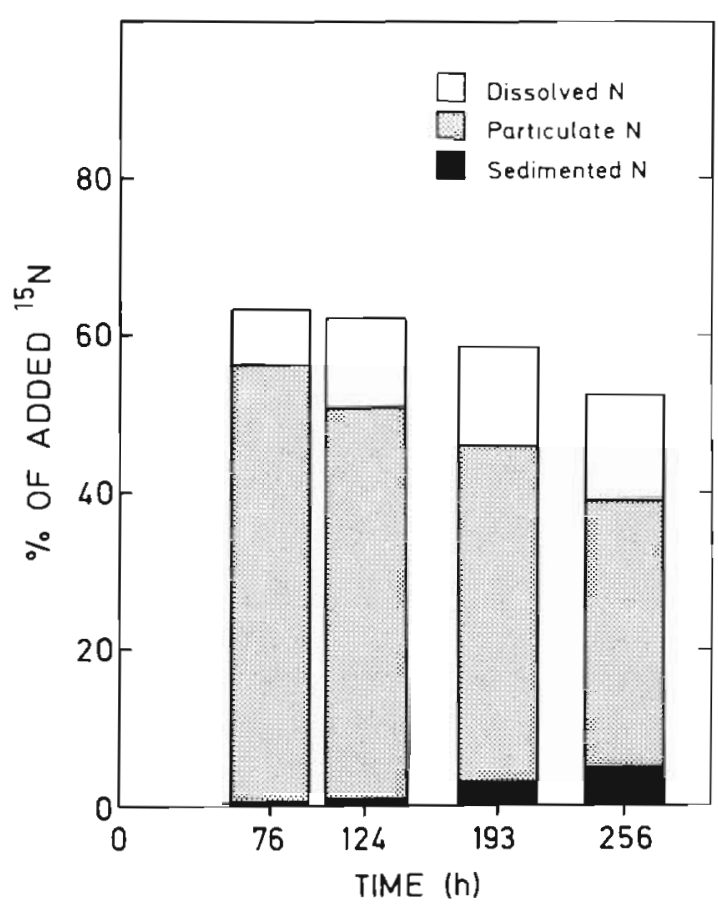

Fig. 4. Recovery of ${ }^{15} \mathrm{~N}$ in dissolved, particulate and sedimented nitrogen as $\%$ of added ${ }^{15} \mathrm{~N}$. Time scales as in Fig. 2

\section{${ }^{15} \mathrm{~N}$ distribution in different fractions}

The increase in atom $\%{ }^{15} \mathrm{~N}$ in the particulate nitrogen was fastest at the beginning of the experiment (Fig. 5). Maximum atom $\%{ }^{15} \mathrm{~N}$ values were reached after $38 \mathrm{~h}$ in the fractions that passed through the $35 \mu \mathrm{m}$ net, while

Table 1. Distribution of particulate nitrogen in different size fractions. Variation in values ranges between 0.8 and $3.3 \%$

\begin{tabular}{|c|c|c|c|c|c|c|c|c|}
\hline \multirow[t]{2}{*}{ Date } & \multirow{2}{*}{$\begin{array}{l}\text { Hours from } \\
\text { start of } \\
\text { experiment }\end{array}$} & \multicolumn{7}{|c|}{ Particulate $\mathrm{N}$ (umol ! ${ }^{-1}$ ) } \\
\hline & & $<5 \mu \mathrm{m}$ & $5-12 \mu \mathrm{m}$ & $12-35 \mu \mathrm{m}$ & $35-100 \mu \mathrm{m}$ & $>100 \mu \mathrm{m}$ & $\begin{array}{l}\text { Sum of } \\
\text { fractions }\end{array}$ & $\begin{array}{l}\text { Unfrac- } \\
\text { tionated }\end{array}$ \\
\hline 12 July & 122 & 1.30 & 0.12 & 0.92 & 0.32 & 0.27 & 2.93 & 4.85 \\
\hline 15 July & 187 & 2.10 & 0.39 & 0.45 & - & - & - & 4.53 \\
\hline 18 July & 252 & 2.96 & 0.51 & 0.41 & 0.23 & 0.51 & 4.62 & - \\
\hline
\end{tabular}

Table 2. Sedimentation rate and ${ }^{15} \mathrm{~N}$ content in sedimented material pumped out of the bottom of the enclosure

\begin{tabular}{|c|c|c|c|c|c|c|}
\hline Date & $\begin{array}{l}\text { Hours from start } \\
\text { of experiment }\end{array}$ & Time diff. & $\begin{array}{l}\text { Sedimentation } \\
\text { rate }\left(\mathrm{mmol} \mathrm{N} \mathrm{m}^{-2} \mathrm{~d}^{-1}\right)\end{array}$ & $\begin{array}{c}{ }^{15} \mathrm{~N} \\
(\text { atom } \%)\end{array}$ & $\begin{array}{c}{ }^{15} \mathrm{~N} \\
(\mathrm{mmol})\end{array}$ & $\begin{array}{l}\% \text { Sedimented } \\
\text { of addition }\end{array}$ \\
\hline 8 July & 16 & & & 4.00 & 0.16 & 0.09 \\
\hline 9 July & 40 & 24 & 0.05 & 8.63 & 0.08 & 0.05 \\
\hline 11 July & 89 & 48 & 0.13 & 10.62 & 0.52 & 0.31 \\
\hline 13 July & 136 & 47 & 0.20 & 11.90 & 0.87 & 0.52 \\
\hline $15 \mathrm{July}$ & 180 & 44 & 0.46 & 12.40 & 1.91 & 1.14 \\
\hline 16 July & 208 & 28 & 0.98 & 12.36 & 2.56 & 1.52 \\
\hline 17 July & 232 & 24 & 0.46 & 12.87 & 1.08 & 0.64 \\
\hline Total & & & & & 7.17 & 4.26 \\
\hline
\end{tabular}




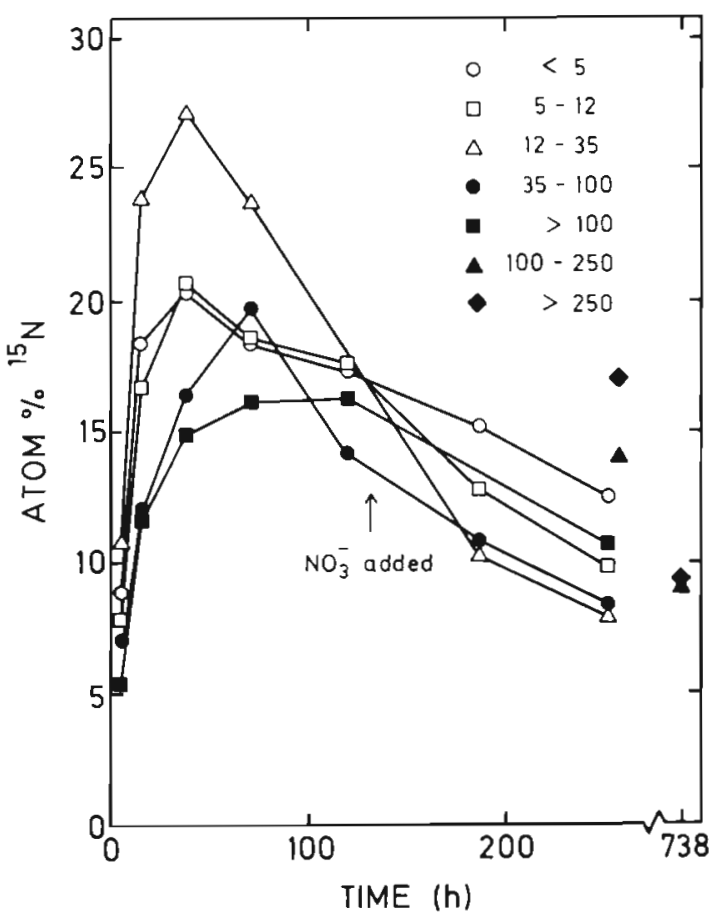

Fig. 5. Distribution of ${ }^{15} \mathrm{~N}$ in different size fractions $(\mu \mathrm{m})$. Time scale as in Fig. 2

fractions larger than 35 m showed maximum ${ }^{15} \mathrm{~N}$ labelling after about $100 \mathrm{~h}$, when the decrease in the smaller fractions had already started. The size fraction between 12 and $35 \mu \mathrm{m}$ showed the fastest ${ }^{15} \mathrm{~N}$-ammonium incorporation rate. This fraction attained 27 atom $\%{ }^{15} \mathrm{~N}$, the highest value recorded. The 2 smaller fractions, $<5 \mu \mathrm{m}$ and 5-12 $\mu \mathrm{m}$, followed each other with a maximum around 20 atom $\%{ }^{15} \mathrm{~N}$ after $38 \mathrm{~h}$. The rate of decrease of ${ }^{15} \mathrm{~N}$ was rather similar in all fractions, except for the 12-35 um fraction that showed a faster decline. Samples of the large fractions, $100-250 \mu \mathrm{m}$ and $>250 \mu \mathrm{m}$, collected directly on plankton nets after $256 \mathrm{~h}$ had the highest atom \% ${ }^{15} \mathrm{~N}$ at this occasion. After $738 \mathrm{~h}$ the label could still be detected in these fractions (Fig. 5).

\section{Uptake of nitrogen nutrients}

From the results, both for the incubation concentration and also when corrected to the in situ concentration (Table 3), a clear preference was observed for ammonium as nitrogen source, followed by urea and nitrate. During the first uptake experiment, about $14 \mathrm{~h}$ after the addition of ${ }^{15} \mathrm{~N}$ to the enclosure, the ammonium uptake rate was probably affected by the addition and was higher, $50 \mathrm{nmol} \mathrm{l}^{-1} \mathrm{~h}^{-1}$, than during the following days when the uptake was about $20 \mathrm{nmol}$ $1^{-1} h^{-1}$. The urea uptake rate varied between 14 and

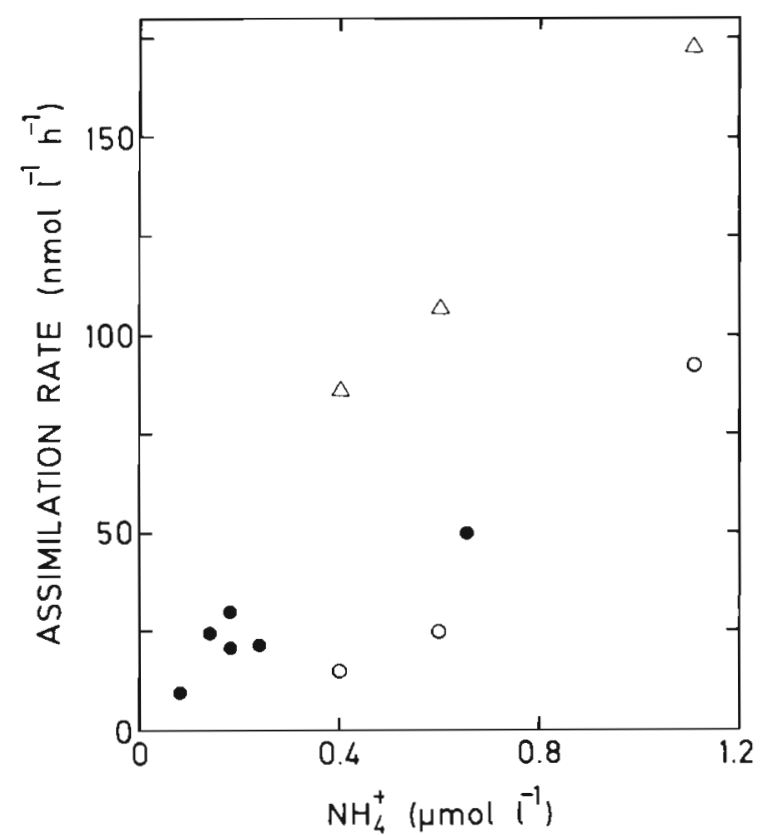

Fig. 6. Rate of ammonium uptake as determined in 3 different ways versus in situ ammonium concentration: from isotope incorporation ( $\bullet$ ), decrease in ammonium concentration (o) and from decrease in ammonium concentrations corrected for an ammonium production rate of $50 \mathrm{nmol} \mathrm{l}^{-1} \mathrm{~h}^{-1}(\mathrm{~A})$

$20 \mathrm{nmol} \mathrm{l}^{-1} \mathrm{~h}^{-1}$ during the first week and the nitrate uptake rate was low, between 3 and 9 nmol $1^{-1} \mathrm{~h}^{-1}$, probably due to the very low in situ concentration. After a week, the ammonium and urea uptake rates decreased to 10 and $12 \mathrm{nmol}^{-1} \mathrm{~h}^{-1}$ respectively. A rough estimate of the ammonium uptake in the beginning of the experiment can be obtained from the decrease in ammonium concentration prior to stabilization at a low level. This is a result of both uptake and regeneration. When correcting for the latter by assuming a regeneration rate of $81 \mathrm{nmol}$ $\mathrm{l}^{-1} \mathrm{~h}^{-1}$ (average of the first 3 measurements), the uptake rates can be estimated. These are, together with the uptake measurements performed with isotope additions, shown in Fig. 6.

After the extra addition of nitrate and phosphate, the average nitrate uptake during the following $4 \mathrm{~d}$, calculated from the decrease in concentration, was $36 \mathrm{nmol}$ $\mathrm{l}^{-1} \mathrm{~h}^{-1}$. Two days after this addition, both the ammonium and urea uptake rates had increased to the same level as the week before.

\section{Regeneration of ammonium}

Results of the ammonium regeneration experiments are shown in Table 3 . The rates prior to the labelling and $1 \mathrm{~d}$ after are similar. After $40.5 \mathrm{~h}$, however, a sharp increase in regeneration rate was observed (115 nmol 
Table 3. Uptake rates of ammonium, nitrate, and urea; regeneration rate of ammonium (nmol $\mathrm{N}^{-1} \mathrm{~h}^{-1}$ ) and regeneration:uptake ratio ( $R$ : $U$ ) inside the enclosure

\begin{tabular}{|c|c|c|c|c|c|c|c|c|c|c|}
\hline \multirow[t]{3}{*}{ Date } & \multirow{3}{*}{$\begin{array}{l}\text { Hours from } \\
\text { start of } \\
\text { experiment }\end{array}$} & \multirow{3}{*}{$\begin{array}{c}\text { Start of } \\
\text { incubation } \\
\text { (h) }\end{array}$} & \multicolumn{6}{|c|}{ Uptake } & \multirow{3}{*}{$\begin{array}{l}\mathrm{NH}_{+}^{+} \\
\text {reg. }\end{array}$} & \multirow{3}{*}{$\begin{array}{c}\quad R: U \\
\text { at inc conc. }\end{array}$} \\
\hline & & & \multicolumn{3}{|c|}{ At incubation conc. } & \multicolumn{3}{|c|}{ At in situ conc. } & & \\
\hline & & & $\mathrm{NH}_{4}^{+}$ & $\mathrm{NO}_{3}^{-}$ & Urea & $\mathrm{NH}_{4}^{+}$ & $\mathrm{NO}_{3}^{-}$ & Urea & & \\
\hline 7 July & & $16: 20$ & & & & & & & 50 & \\
\hline 8 July & 16.3 & $11: 45$ & 64 & 9 & 17 & 50 & 4 & 14 & 40 & 0.6 \\
\hline 9 July & 40.5 & $12: 00$ & 45 & 28 & 26 & 21 & 9 & 18 & 1.15 & 2.6 \\
\hline 9 July & 52.5 & $24: 00$ & 40 & 8 & 22 & 22 & 3 & 16 & 89 & 2.2 \\
\hline 11 July & 86.5 & $10: 00$ & 61 & 19 & 26 & 25 & 6 & 20 & 28 & 0.5 \\
\hline 13 July & 132.5 & $08: 00$ & 34 & 10 & 16 & 10 & 5 & 12 & - & \\
\hline 15 July & 185 & $12: 30$ & 64 & - & 27 & 30 & $36^{a}$ & 20 & 55 & 0.8 \\
\hline
\end{tabular}

$\left.\mathrm{I}^{-1} \mathrm{~h}^{-1}\right)$, which subsequently declined, reaching its lowest value after $86.5 \mathrm{~h}\left(28 \mathrm{nmol} \mathrm{l}^{-1} \mathrm{~h}^{-1}\right)$. After the addition of nitrate, however, the regeneration rate increased to the initial value. Average ratio of regeneration rates to uptake rates ( $R$ : $U$ ) was 1.5 , when using the uptake rates at incubation concentrations. Highest ratios were observed on 9 July, since the increase in regeneration rates on these occasions was not accompanied by an increase in ammonium uptake rates.

\section{DISCUSSION}

When water is trapped inside an enclosure it becomes more stratified and as a consequence a higher sedimentation rate will occur (Steele et al. 1977). According to Andersson \& Rahm (1989), who also performed measurements during this study, the Askö enclosure was dominated in the upper part by vertical circulation that was less intensive than outside. From their measurements of temperature profiles they concluded that the upper part was homogeneous with a temperature of $\mathrm{ca} 18^{\circ} \mathrm{C}$, and the lower part stratified. The upper $4 \mathrm{~m}$ were well mixed in all of their measured cases, and the mixed depth usually exceeded $6 \mathrm{~m}$. The observed stratification is clearly due to a thermocline outside the enclosure, and the response was dampened inside. Even after an induced mixing, stratification was reestablished within $2 \mathrm{~h}$. This might have influenced the chemical fluxes and the plankton distribution. During this experiment, Tobiesen (1989) noticed a gradual change in the population towards a greater proportion of small organisms ( $<5 \mathrm{pg}$ C) and a decreased proportion of large microorganisms ( $>50 \mathrm{pg}$ C). A comparable change has also been indicated in other mesocosm experiments (e.g. Bienfang 1982). He suggested that increased sedimentation of larger nonmotile plankton was caused by decreased vertical transport due to stratification. Because we worked with integrated samples we could see no effect from stratification. On one occasion, after $68 \mathrm{~h}$, separate depths $(1,4$, and $7 \mathrm{~m})$ were sampled. At this time, nutrient concentrations did not vary with depth, but particulate matter showed some variation, being least abundant in the intermediate depth $\left(3.8 \mu \mathrm{mol} \mathrm{N} \mathrm{l^{-1 }}\right)$ and more concentrated at the

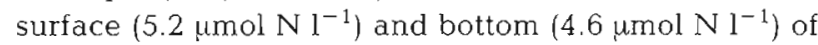
the enclosure.

Compared with other enclosure experiments, the sedimentation rate seems relatively low. In our case, the concentration of particulate nitrogen was fairly constant during the investigated period. Harrison \& Davies (1977) reported a settling rate of $1.57 \mathrm{mmol} \mathrm{N}$ $\mathrm{m}^{-2} \mathrm{~d}^{-1}$ inside their enclosure, and of $0.86 \mathrm{mmol} \mathrm{N} \mathrm{m}^{-2}$ $\mathrm{d}^{-1}$ outside. Our values, obtained by using the area of the uppermost cylinder $\left(18.1 \mathrm{~m}^{2}\right)$, are in the range of 0.05 to $0.98 \mathrm{mmol} \mathrm{N} \mathrm{m}^{-2} \mathrm{~d}^{-1}$, with an average of $0.38 \mathrm{mmol} \mathrm{m}^{-2} \mathrm{~d}^{-1}$, i.e. less than half the quoted values. The higher $\mathrm{C} / \mathrm{N}$ ratio in the sedimented material as compared to the particulate material in the water indicates a more rapid mineralization of nitrogen than carbon. The amount of nitrogen in the accumulated sedimented material during the experiment was only $17 \%$ of the particulate nitrogen present initially. Since only $4.3 \%$ of the added ${ }^{15} \mathrm{~N}$ was recovered in the sedimented material it is likely that the main part of this pool that was originally in the enclosure must have been detritus. That a significant part of the organic material mineralized was detritus is also indicated by the values of $\mathrm{Y}\left({ }^{15} \mathrm{~N}\right.$ content of the organic nitrogen mineralized to ammonium) which varied between 5.6 and 13 , with a mean value of 9.9 atom $\%{ }^{15} \mathrm{~N}$. This is low compared to the amount of label detected in the particulate material (Fig. 5).

On the last day budgeted, $53 \%$ of the ${ }^{15} \mathrm{~N}$ initially present can be found (Fig. 4). This corresponds to a loss of $80 \mathrm{mmol}{ }^{15} \mathrm{~N}$. If we assume that the sedimenting material had an average of 12 atom $\%{ }^{15} \mathrm{~N}$ (see Table 2), a loss of $670 \mathrm{mmol}(9.3 \mathrm{~g}) \mathrm{N}$ during the 
experiment would have occurred. The low recovery of the ${ }^{15} \mathrm{~N}$ initially present may partly be due to incomplete recovery of sedimented matter. While diving after the experiment had ended, K. Koop (pers. comm.) observed that there was particulate material deposited on the walls of the conical lower part of the enclosure. This material would not have been sampled by the pumping from the bottom of the cone. Ducklow et al. (1986) cites a personal communication (from Baird) indicating that the estimated average recovery of sediment was $14 \%$ in enclosures similar to ours. Assuming a similar efficiency in our enclosure, sedimentation measurements would result in a sedimentation of ca $30 \%$ of the added ammonium. If the assumption that a large part collects on the bottom walls in the enclosure is true, there is also a possibility that the temporal pattern of sedimentation is incorrect. If the layer becomes thicker with time, it is likely that some of it will slide down to the collecting tube in the cone. The apparently increased sedimentation rate during the later part of the experiment could thus be due to earlier sedimented material.

From the discrepancies found by Glibert et al. (1982) when comparing the disappearance of ${ }^{15} \mathrm{~N}$ from the ammonium pool with the recovery of ${ }^{15} \mathrm{~N}$ in the particulate fraction, Laws (1984) argued that up to $40 \%$ of the label originally added could not be accounted for at the end of the incubation. After rejecting nitrification and adsorption of ammonium onto surfaces, he suggested that the missing ${ }^{15} \mathrm{~N}$ had been released as dissolved organic nitrogen, although the labelling of this fraction had not been measured. The amount of the added ammonium that in our case could be recovered in the total dissolved nitrogen fraction increased steadily from $14.7 \mathrm{mmol} \mathrm{N}$ after $76 \mathrm{~h}$ to $22.7 \mathrm{mmol}$ after $756 \mathrm{~h}$. The highest value constituted $14 \%$ of the ${ }^{15} \mathrm{~N}$ that was added initially. Consequently, this would in this case not support the suggestion that the dissolved organic nitrogen is a significant sink for ${ }^{15} \mathrm{~N}$ on a time scale of days, although we did not study shorter time effects. There might have been a rapid recycling of dissolved organic nitrogen during the first days which was not detected in the present experiment. The accumulation of ${ }^{15} \mathrm{~N}$ observed may, on the other hand, be an indication of a transfer of nitrogen to a refractive pool of dissolved organic nitrogen.

A rapid uptake of the ${ }^{15} \mathrm{~N}$-ammonium added was noted, with a clear difference in incorporation occurring among the size fractions (Fig. 5). The temporal difference in maximum labelling between the $<35 \mu \mathrm{m}$ fractions and the $35-100 \mu \mathrm{m}$ fraction was around $30 \mathrm{~h}$. In the fraction $>100 \mu \mathrm{m}$, however, the rate of labelling was somewhat slower, with maximum labelling occurring between 30 and $80 \mathrm{~h}$ after the smaller fractions. This indicates that the fractions below and above $35 \mu \mathrm{m}$ were relatively dominated by producers and consumers, respectively. The most active size fraction in incorporating the labelled nitrogen was $12-35 \mu \mathrm{m}$. This was dominated by primary producers, mainly naked dinoflagellates (Gymnodinium) and green algae (Desmidiaceae) (A. Tobiesen pers. comm.). The fractions $<12 \mu \mathrm{m}$, dominated by coccoid cyanobacteria $(<5 \mu \mathrm{m})$ and Chrysophyceae $(5-12 \mu \mathrm{m})$, doubled their particulate nitrogen content after the extra addition of nitrate, indicating a rapid uptake of the nutrient. The 2 larger fractions (35-100 and $>100 \mu \mathrm{m})$ differed (S. Johansson pers. comm.), the smaller being dominated by rotifers (Keratella) and the larger by copepods - mainly Eurytemora. The steeper slope of ${ }^{15} \mathrm{~N}$-incorporation for $35-100 \mu \mathrm{m}$ might be interpreted as a faster growth rate for rotifers.

A variation in the percentage of particulate detritus (which would not take up ${ }^{15} \mathrm{~N}$ ) in the different fractions could influence the atom $\%{ }^{15} \mathrm{~N}$ in the PN. This would predominantly influence the labelling rates in the smallest fractions. Because the decrease in labelling of the 12-35 $\mu \mathrm{m}$ fraction is fastest and also gives a final value that is lower than the other fractions, we believe that the conclusion that this fraction assimilates nitrogen most actively is justified.

Wheeler \& Kirchman (1986), who examined ammonium uptake in both coastal and deep-sea Atlantic waters, estimated that an average of $75 \%$ of the uptake was by bacteria, although the variation was considerable, and at times the eucaryotic ammonium uptake could have been high. Since our experiment started with an addition of nitrogen, one possibility for the lower activity in the smallest size fraction could be that the bacteria with their lower N:P ratio were experiencing a higher degree of phosphorus limitation than the algae. This is supported by the immediate increase (by $50 \%$ ) in bacterial biomass that occurred after the addition of nitrate and phosphate at $132 \mathrm{~h}$ (Tobiesen 1989).

Nutrient uptake rates showed a preference in the order ammonium > urea > nitrate, as would be expected for a population that was adapted to nutrientlimited waters. This is also in agreement with results of another study carried out in the Baltic Sea during July and August 1982 (Sörensson \& Sahlsten 1987). After the nitrate addition, the nitrate concentration decreased at an average rate of $36 \mathrm{nmol} \mathrm{l}^{-1} \mathrm{~h}^{-1}$. There was a decreased nitrate consumption rate (Fig. 2) between 184 and 215 h, i.e. on the 15 and 16 July. This coincided with a marked peak in nitrite concentration and also an increase of in situ ammonium concentration. We cannot fully explain the lowered uptake activity and nitrite production during this period. One explanation could be that some compound other than nitrogen or phosphorus was limiting production, and 
that therefore all the nitrate taken up was not assimilated, but rather being excreted as nitrite. This could have been brought about by the increased bacterial biomass that almost doubled after the nitrate addition (Tobiesen 1989). A reduced uptake would also explain the increased ammonium concentration. Another explanation could be a temporary burst of nitrifying activity. If this is the case, the nitrate uptake could be unaffected and a production of nitrate would explain the apparent decrease in nitrate consumption.

The sharp increase in the rates of ammonium regeneration observed after $40.5 \mathrm{~h}$ may be due to increased nitrogen cycling in the mesocosm, caused by the extra input of ammonium. This coincides with the $37 \%$ increase in PN which was observed from 70.5 to $122 \mathrm{~h}$. This increase is after the ${ }^{15} \mathrm{~N}$ labelling peak of the size fractions $<35 \mu \mathrm{m}$ (which occurred after $30 \mathrm{~h}$ ). On 9 July highest rates of flagellate grazing on bacteria were also observed (Tobiesen 1989). Consequently, an increase in primary production caused an increase in biomass, and an increased grazing pressure, presumably on both phytoplankton and bacteria. Organically bound nitrogen would thus be released, and an increase in the rate of ammonium regeneration would occur.

We have some indications that either the regeneration rates are overestimated or the uptake rates are underestimated. This is seen both from the plot of ammonium decrease, corrected for ammonium production (Fig. 6) and from the isotope incubations. On the first day after the ${ }^{15} \mathrm{~N}$-ammonium addition, the rate of ammonium uptake was higher than ammonium regeneration, while after $40.5 \mathrm{~h}$ the reverse situation appeared, as discussed above. This has also been found by other authors, e.g. Wheeler \& Kirchman (1986), who stated that on a coastal station the ammonium regeneration 'often exceeded ammonium uptake rates'. This may be an effect of bottle confinement, as pointed out by Koike et al. (1982). They compared ratios of regeneration/uptake for ammonium from different enclosure experiments. In those where the rate determinations had been done in separate bottle incubations (Harrison 1978 ) the ratios were $>1$, while rates calculated from in situ ${ }^{15} \mathrm{~N}$ determinations (Koike et al. 1982) exhibited ratios of $<1$; thus rates of uptake were exceeding those of regeneration. Their explanation was that the particulate material, assumed to be the source of the ammonium formed, is kept within the bottle, and not able to settle out, as in the enclosure. Because the sedimentation rate in the enclosure was relatively low, this error should be small in our bottle incubations. Besides the effects mentioned above, bottle incubations could overestimate the in situ regeneration rate if the handling of the water sample destroys intact cells, thus releasing material that is easily decomposed. This artifact will not affect the determination of the nutrient uptake rate to any greater extent because we used saturating amounts of substrates

A consistently higher rate of ammonium regeneration in relation to the uptake rates would result in measurably elevated ammonium concentrations. This is not seen in the in situ determinations. Although the excess ammonium could have been oxidized through nitrification, a high nitrification rate in the upper water column seems quite unlikely. Nitrification was not measured in this experiment, but earlier summer measurements from the Baltic show a maximum rate of $9 \mathrm{nmol} \mathrm{Nl}^{-1} \mathrm{~d}^{-1}$ (Enoksson 1986) above $60 \mathrm{~m}$ depth. The discrepancies reported here correspond to about 70 times this rate.

The most likely explanation for the discrepancies is the use of high ammonium additions in the isotope dilution experiments, and not correcting the determined rates for the in situ ammonium concentrations. According to the Blackburn-Caperon model (Blackburn 1979. Caperon et al. 1979), the measured rate of ammonium regeneration should be independent of the ammonium concentration. Several authors, however have proposed that the regeneration rates obtained with high ammonium additions are potential rates, and therefore only comparable to uptake rates determined with saturating ammonium concentrations (Harrison 1978, Harrison et al. 1983, Cochlan 1986, Selmer 1988). Comparing the regeneration rates with uptake rates at incubation concentrations in this study, $R$ : $U$ equals on average 1.5, which is more reasonable for an ecosystem in steady state. Large variations are seen, however, in the individual $\mathrm{R}$ : $\mathrm{U}$ ratios (Table 3 ). When the regeneration rate had declined (on 11 July) the ammonium uptake rate was still of the same magnitude as before, indicating that this process is still sustained by the large ammonium regeneration observed earlier. Accordingly, the ambient ammonium concentration declined after 11 July.

The phosphate uptake after the nitrate and phosphate addition, calculated from the decrease in concentration, was $1.5 \mathrm{nmol}^{-1} \mathrm{~h}^{-1}$, indicating an uptake ratio of nitrate/phosphate equal to 24 . If the uptake of ammonium and urea also is included, the N/P uptake ratio increases to 57 . Assuming that the phytoplankton community of the enclosure had a N/P ratio close to the Redfield ratio (16/1), then the surplus nitrogen consumption (62 nmol $\mathrm{l}^{-1} \mathrm{~h}^{-1}$ ) could be due to several processes other than phytoplankton nutrient uptake. One explanation could be denitrification, although we consider it unlikely that this could account for a major part, since it would only occur in the sedimented matter in the bottom of the enclosure. The most likely explanation is a regeneration of phosphate. The phosphate regeneration would have to amount to $3.9 \mathrm{nmol} \mathrm{PO}_{4}^{3-}$ $\mathrm{l}^{-1} \mathrm{~h}^{-1}$ to compensate for the excess nitrogen consumed, if this was to be assimilated into phytoplankton. 
The one regeneration measurement that was carried out after the nitrate/phosphate addition gave an ammonium regeneration rate of $55 \mathrm{nmol}^{-1} \mathrm{~h}^{-1}$. If we assume a ratio of $16 / 1$ in the regeneration of ammonium and phosphate, this would correspond to a phosphate regeneration of $3.4 \mathrm{nmol} \mathrm{l}^{-1} \mathrm{~h}^{-1}$ and thus explain the discrepancy.

\section{CONCLUSIONS}

We have shown that, by using a mesocosm, it is possible to follow the rate of ${ }^{15} \mathrm{~N}$-incorporation into different size fractions. Clear differences in the incorporation into producers and consumers was noted. We have also determined the distribution of ${ }^{15} \mathrm{~N}$ in the different pools (dissolved, particulate and sedimented material) within the enclosure, although recovery was never complete. Rate determinations were performed using ${ }^{15} \mathrm{~N}$ - and ${ }^{14} \mathrm{~N}$-enrichments on prelabelled water from the enclosures, and by comparing the 2 labellings we could calculate the uptake rates of ammonium, nitrate, and urea and regeneration of ammonium. The nitrogen nutrition was largely based on ammonium, except after the addition of a large amount of nitrate.

Acknowledgements. We are grateful to Peter J. leB. Williams and Fredrik Wulff for initiating this project, to Fredrik Wulff, Klaus Koop and the staff at the Askö Laboratory for logistic support, to Sif Johansson and August Tobiesen for species determination and also for access to unpublished data for which we also thank Lars Andersson and Lars Rahm. We further thank Patricia Conway for linguistic advice, Nancy Ilenius for drawing the figures, Ulf Rönner for helpful comments on the manuscript, Ernst S. Selmer for valuable help with the mathematics, Viveka Enoksson for help with the development of the DON extraction method, and Anna-Kerstin Thell for skillful technical assistance. This work was supported by the Swedish Natural Science Research Council, grant no. 1940-102 and by the Swedish Environment Protection Board, grant no. 5339195-9.

\section{LITERATURE CITED}

Andersson, L., Rahm, L. (1989). Thermally driven circulation within an experimental enclosure. Estuar. cstl Shelf Sci. (in press)

Armstrong, F. A. J., Stern, C. R., Strickland, J. D. H. (1967). The measurement of upwelling and subsequent biological processes by means of the Technicon AutoAnalyser and associated equipment. Deep Sea Res. 14: 381-389

Bienfang, P. K. (1982). Phytoplankton sinking-rate dynamics in enclosed experimental ecosystems. In: Grice, G. D., Reeve, M. R. (eds.) Marine mesocosms. Biological and chemical research in experimental ecosystems. SpringerVerlag, New York, p. 261-274

Blackburn, T. H. (1979). Method for measuring rates of $\mathrm{NH}_{4}^{+}$ turnover in anoxic marine sediments, using a ${ }^{15} \mathrm{~N}-\mathrm{NH}_{4}^{+}$dilution technique. Appl. environ. Microbiol. 37: 760-765

Caperon, J., Schell, D.. Hirota, J, Laws, E. (1979). Ammonium excretion rates in Kaneohe Bay, Hawaii, measured by a ${ }^{15} \mathrm{~N}$ isotope dilution technique. Mar. Biol. 54: 33-40

Cochlan, W. P. (1986). Seasonal study of uptake and regeneration of nitrogen on the Scotian Shelf. Cont. Shelf Res. 5: $555-557$

Collos, Y (1987). Calculations of ${ }^{15} \mathrm{~N}$ uptake rates by phytoplankton assimilating one or several nitrogen sources. Appl. Radiat. Isot. 38: 275-282

Davies, J. M. (1983). The use of large enclosures in marine microbial research. In: Hobbie, J. E., Williams, P. J. leB. (eds.) Heterotrophic activity in the sea. Plenum Press, New York, p. 465-479

DeManche, J. D., Curl, H., Jr., Coughenower, D. D. (1973). An automated analysis for urea in seawater Limnol. Oceanogr. 18: 686-689

Ducklow, H. W., Purdie, D. A., Williams, P. J. leB., Davies, J. M. (1986). Bacterioplankton: a sink for carbon in a coastal marine plankton community. Science 232: 865-867

Dugdale, R. C., Goering, J. J. (1967). Uptake of new and regenerated forms of nitrogen in primary productivity. Limnol. Oceanogr. 12: 196-206

Enoksson, V. (1986). Nitrification in the Baltic Sea: comparison of three isotope techniques. Appl. environ. Microbiol. 51: $244-250$

Glibert, P. M., Lipschultz, F., McCarthy, J. J., Altabet, M. A. (1982). Isotope dilution models of uptake and remineralization of ammonium by marine plankton. Limnol. Oceanogr. 27: 639-650

Grice, G. D., Reeve, M. R. (1982). Marine mesocosms. Biological and chemical research in experimental ecosystems. Springer-Verlag, New York

Harrison, W. G. (1978). Experimental measurements of nitrogen remineralization in coastal waters. Limnol. Oceanogr. 23: $684-694$

Harrison, W. G., Davies, J. M. (1977). Nitrogen cycling in a marine planktonic food chain: nitrogen fluxes through the principal components and the effects of adding copper. Mar. Biol. 43: 299-306

Harrison, W. G., Douglas, D., Falkowski, P., Rowe, G., Vidal, J. (1983). Summer nutrient dynamics of the Middle Atlantic Bight: nitrogen uptake and regeneration. J. Plankton Res. 5: $539-556$

Harrison, W G., Eppley, R. W., Renger, E. H. (1977). Phytoplankton nitrogen metabolism, nitrogen budgets and observations on copper toxicity: controlled ecosystem pollution experiment. Bull mar. Sci. 27: 44-57

Hattori, A., Koike, I., Ohtsu, N., Goering, J. J., Boisseau, D (1980). Uptake and regeneration of nitrogen in controlled aquatic ecosystems and the effects of copper on these processes. Bull mar. Sci. 30: 431-443

Koike, I., Hattori, A., Takahashi, M., Goering, J. J. (1982). The use of enclosed experimental ecosystems to study nitrogen dynamics in coastal waters. In: Grice, G. D., Reeve, M. R. (eds.) Marine Mesocosms. Biological and chemical research in experimental ecosystems. Springer-Verlag, New York, p. 291-303

Koroleff, F. (1976). Determinations of nutrients. In: Grasshoff, K. (ed.) Methods of seawater analysis. Verlag Chemie, Weinheim, p. 117-182

Kristiansen, S. (1983). Urea as a nitrogen source for the phytoplankton in the Oslofjord. Mar Biol. 74: 17-24

Kristiansen, S., Paasche, E. (1982). Preparation of ${ }^{1.5} \mathrm{~N}$ labelled phytoplankton samples of optical emission spectrometry. Limnol. Oceanogr. 27: 373-375

Larsson, U., Hagström, $\AA$. (1982). Fractionated phytoplankton primary production, exudate release and bacterial production in Baltic eutrophication gradient. Mar. Biol. 67: 57-70 
Laws, E. (1984). Isotope dilution models and the mystery of the vanishing ${ }^{15} \mathrm{~N}$. Limnol. Oceanogr. 29: 379-386

Newell, B. S., Morgan, B., Cundy, J. (1967). The determination of urea in seawater. J. mar. Res. 25: 201-202

Olson, R. J. (1981). ${ }^{15} \mathrm{~N}$ tracer studies of the primary nitrite maximum. J. mar Res. 39: 203-226

Selmer, J.-S. (1988). Ammonium regeneration in the marine environment. Ph.D. thesis, Dept. Marine Microbiology, Univ. Göteborg

Selmer, J.-S., Sorensson, F. (1986). New procedure for the extra ction of ammonium from natural waters for ${ }^{15} \mathrm{~N}$ isotopic ratio determinations. Appl. environ. Microbiol. 52: $577-579$

Steele, J. H. (1979). The use of experimental ecosystems. Phil. Trans. R. Soc. Lond. B 286: 583-595

Steele, J. H., Farmer, D. M., Henderson, E. W. (1977). Circulation and temperature structure in large marine enclosures. J. Fish. Res. Bd Can. 34: 1095-1104

This article was submitted to the editor
Sörensson, F., Sahlsten, E. (1987). Nitrogen dynamics of a cyanobacteria bloom in the Baltic Sea - new versus regenerated production. Mar. Ecol. Prog. Ser. 37. 277-284

Tobiesen, A. (1989). Population dynamics. In: Wulff, F., Koop, $K$. (eds.) An interdisciplinary study on community metabolism, structure, nutrient transfer and cycling in a plankton community. Contrib. Askö Lab., Univ. Stockholm (in press)

Wheeler, P. A., Kirchman, D. L. (1986). Utilization of inorganic and organic nitrogen by bacteria in marine systems. Limnol. Oceanogr. 31: 998-1009

Williams, P. J. leB. (1981). Microbial contribution to overall marine plankton metabolism: direct measurement of respiration. Oceanologica Acta 4: 359-363

Wulff, F., Koop, K. (eds.) (1989). An interdisciplinary study on community metabolism, structure, nutrient transfer and cycling in a plankton community. Contrib. Askö Lab., Univ. Stockholm

Manuscript first received: December 22, 1987

Revised version accepted: April 26, 1989 